\title{
WHAT CAN WE LEARN FROM THE PAST? A CENTURY OF CHANGES IN VULNERABILITY TO FLOODS IN THE TER RIVER BASIN
}

\author{
ANNA RIBAS PALOM ${ }^{\text {* }}$, DAVID SAURÍ PUJOL ${ }^{2}$ \\ ${ }^{1}$ Department of Geography, Universitat de Girona, Spain. \\ ${ }^{2}$ Department of Geography, Universitat Autònoma de Barcelona, Spain.
}

\begin{abstract}
The objective of this article is to analyze from a historical perspective the impacts of floods in the Ter river basin of North-Eastern Catalonia between 1900 and 2020. The analysis focuses on the three factors that, according to the IPCC, intervene in the definition of vulnerability, namely exposure, susceptibility and adaptive capacity. The analysis has been structured in four historical periods with two or three catastrophic flood episodes for each period. Although a lack of reliable data and studies on especially economic losses must be acknowledged, results obtained indicate that flood exposure has increased in the basin but vulnerability may have decreased as a result of decreased susceptibility and, especially, of a significant increase in adaptive capacity. Both in terms of victims and relative economic losses, the impacts of the floods would show a downward trend that, among other factors, tends to correlate positively with the increasing levels of economic development and well-being experienced in the basin during the last century.
\end{abstract}

\section{¿Qué podemos aprender del pasado? Un siglo de cambios en la vulnerabilidad a las inundaciones en la cuenca del río Ter}

RESUMEN. Este artículo tiene por objetivo analizar, desde una perspectiva histórica, cuáles han sido los impactos de las inundaciones en la cuenca del río Ter durante el período comprendido entre los años 1900 y 2020 . El análisis se centra en los tres factores que, según la aproximación a la vulnerabilidad que propone el IPCC, intervienen en el impacto de las inundaciones: exposición, susceptibilidad y capacidad de adaptación. Metodológicamente, este análisis se ha estructurado a partir de la selección de cuatro períodos históricos y dos o tres episodios de inundación catastróficos para cada período. Aunque faltan datos y estudios concluyentes especialmente sobre pérdidas económicas, los resultados obtenidos indican que, si bien la exposición a las inundaciones ha aumentado y los daños han seguido una tendencia ascendente, la vulnerabilidad ha disminuido a consecuencia de la disminución en la susceptibilidad y, especialmente, a un importante aumento de la capacidad de adaptación. Tanto en términos de víctimas como de pérdidas económicas relativas, los impactos de las inundaciones mostrarían una tendencia a la baja que, entre otros factores, tiende a correlacionarse positivamente con los niveles crecientes de desarrollo económico y bienestar que ha experimentado esta cuenca.

Key words: Historical floods, vulnerability, exposure, susceptibility, adaptive capacity, Ter river basin.

Palabras clave: Inundaciones históricas, vulnerabilidad, exposición, susceptibilidad, capacidad de adaptación, cuenca del Ter.

Received: 10 June 2020

Accepted: 16 September 2020 
*Corresponding author: Anna Ribas, Department of Geography, Universitat de Girona, C/ Ferrater I Mora, 1, 17004 Girona, Spain. E-mail address: anna.ribas@udg.edu

\section{Introduction}

Throughout human history, floods have been and remain the most important natural hazard worldwide regarding people affected (Kron, 2015; Angelakis et al., 2020). Between 1980 and 2019, flooding accounted for some 40 percent of worldwide natural disaster losses, totaling more than 1,092 billion US dollars (Munich Re, 2019). Moreover, flood occurrence appears to be increasing. For example, the number of major world floods per year rose from an annual average of 127 for the period 1995-2004 to an average of 171 in the period 2005-2014 (Munich Re, 2019). In Europe, between 1980 and 2010, 37 European countries recorded more than 3,500 flood episodes (EEA, 2016) but possible many more did not reach official statistics (Paprotny et al., 2018).

Climate change exerts an increasing influence in future flood trends. In Europe, for instance, floods associated with return periods of 100 years may double their frequency around 2050 (Alfieri et al., 2015). Ensuing impacts are estimated to be very high with absolute economic damages increasing twenty-fold by the end of this century, especially in Asia (Winsemius et al., 2016). In Europe, flood losses would increase five-fold by 2050 and 17-fold by 2080 (EEA, 2016). Most studies attribute the bulk of these growing impacts to socioeconomic factors rather than to natural factors. Hence, observed and expected losses are primarily related to an increase in exposure, basically the accumulation of population and wealth in flood prone areas which multiplies the potential of losses (Barredo, 2009; Rosenzweig et al., 2018; UNISDR and CRED, 2019). In Europe, Paprotny et al. (2018) document increases both in annual flooded areas and in number of people affected since 1870 .

However, increasing exposure does not necessarily translate into increasing negative impacts, at least in terms of human mortality. On the contrary, several studies have found declining trends in flood related mortality. In Europe, decline has been consistent at least since 1950 (Mudelsee et al., 2003; Jongman et al., 2015; Tanoue et al., 2016; Paprotny et al., 2018). Regarding economic losses, the picture may be more complex. In general, it can be argued that economic losses increase in absolute terms, but when "normalized" (e.g. considered in the context of the evolution of population, GDP and GDP per capita) may remain stable or even decrease (Barredo, 2009). Neumayer and Barthel (2011), for instance, did not find significant upward trends in normalized disaster losses for the period 1980-2009. Likewise, in a study of insured flood losses in Spain between 1971 and 2008, Barredo et al. (2012) did not observe an increasing pattern either.

Despite problems of under-reported smaller episodes and the always difficult monetary evaluation of all economic and non-economic losses, the impacts of floods using the metrics of victims and of economic damages appear to be historically declining a least in Europe and possibly in the world as well. For some authors, there is a clear relationship between the impacts of natural disasters and the level of development (Burton et al., 1978). Rising standards of living between 1980 and 2010 coincided with falling mortality and falling economic losses normalized according to population and GDP (Jongman et al., 2015). In this sense losses and wealth are intrinsically related (Schumacher and Strobi, 2011).

The findings summarized above concur with the hypothesis that exposure alone cannot give a meaningful assessment of flood impacts. Hence, impacts respond to changes in exposure to flood events but also and perhaps more importantly to changes in susceptibility such as the characteristics of the population and the socioeconomic activities potentially exposed to the hazard and to changes in adaptive capacity or ability to respond adequately to extreme events. Vulnerability would finally result from the dynamic interplay between these three components: exposure, susceptibility and adaptive capacity, according to the approach to vulnerability taken by the IPCC (IPCC, 2014, Schmidt-Thomé and 
Grieving, 2013) that will be followed in this article. Historical changes in the three components of vulnerability would provide a reasonable explanation for the temporal evolution of flood related impacts and its human, social and economic significance. All three components have underlying causes that need to be unraveled (Blaikie et al., 2005). Exposure is primarily related to flood events and its characteristics in terms of magnitude, frequency and spatial and temporal reach (Burton et al., 1978). Susceptibility calls for attention to age, physical condition, class, gender, race and ethnicity, education and income, among other social variables, of the people and communities in the basin. Adaptive capacity is related to wealth but also to the quality of democracy, governance and rights (Ensor et al., 2015). All components of vulnerability are deeply interwoven with historical and existing patterns of human occupation and use of the land, and with the socioeconomic model and related institutions, norms and values inspiring these patterns. According to Jongman et al. (2015), vulnerability remains an insufficiently explored variable and yet of high significance for projecting adequately future trends in flood victims and losses. Historical approaches to the occurrence and impact of floods may shed light therefore on changing views on the relations between extreme natural events and human societies.

Our objective in this paper is to offer a historical perspective on floods and their impacts in the Ter River basin (Northeastern Iberian Peninsula) by examining for approximately the last century exposure, susceptibility and adaptive capacity to these phenomena. More specifically, we will assess how several large floods since the early 20th century disrupted population, economic activities and infrastructures; what were in each period the responses to avoid or reduce future losses and what lessons could be learnt to reduce future vulnerability. By using a historical perspective, we can identify change, permanence and inertial factors for a given area regarding flood occurrence, responses and impacts as well as discourses and future strategies for flood control. Our main hypothesis, backed by recent research on long term impacts of natural hazards and of floods as summarized above, is that during the last century exposure to floods has increased and that damages have followed a consistently upward trend. However, overall vulnerability would have decreased owing to a decrease in certain dimensions of susceptibility and above all to an important increase in adaptive capacity (Jongman et al., 2015). Both in terms of victims and of relative economic losses the impacts of floods would show a downward trend which, among other variables, tends to correlate positively with increasing levels of economic development and welfare (Burton et al., 1978).

The paper is organized as follows. After this introduction, we present the study area and the materials and methods chosen for undertaking the analysis. Next, we begin our analysis of the changing conditions in the physical characteristics of catastrophic floods by selecting an analyzing four major historical periods in the Ter, and two or three major flood episodes for each period, ranging from 1900 to 2020. Each event is set in the dominant territorial model in the different sub basin areas of each period, and the characterization of exposure, susceptibility, and adaptive capacity are estimated for each territorial unit and period in order to estimate the respective vulnerabilities. Then, we discuss the results in the light of the main hypothesis formulated in the introduction and conclude with a summary of the paper and the main lesson learnt regarding the evolving character of vulnerability to floods in the study area.

\section{Study area}

With a length of $195 \mathrm{~km}$ and a basin area of $3,010 \mathrm{~km}^{2}$, the Ter River is, together with Llobregat River, the most important fluvial course in Eastern Catalonia, flowing from the Pyrenees to the Mediterranean Sea (Fig. 1). Altitudinal differences from near 3,000 meters to sea level in less than 200 kilometers and a complex orography shape the large variety of climates and natural landscapes present in the basin. Mediterranean influences govern the pluvial and hydrological regime of much of the basin, with a maximum of rainfall in autumn and spring, dry summers with occasional rainfall outbursts, and winters with little rain. Central European influences accentuate the secondary winter drought, intensify spring and summer rainfall, and favor occasional but intense winter frosts. Highest precipitation, with 
average annual values above $1100 \mathrm{~mm}$, occurs in the headwaters and decreases towards the coast where average values fall to $550 \mathrm{~mm}$. Current average annual flow of the Ter River attains $816 \mathrm{hm}^{3}\left(26.6 \mathrm{~m}^{3} / \mathrm{s}\right.$. at the mouth). The Ter River is regulated by two reservoirs, Sau and Susqueda, that, together with the secondary reservoir of El Pasteral, allow the transfer of up to $7.5 \mathrm{~m}^{3} / \mathrm{s}$ and some $195 \mathrm{hm}^{3}$ every year to Barcelona. Additionally, $1,4 \mathrm{~m}^{3} / \mathrm{s}$ are directed to the urban area of Girona and to the Center of the Costa Brava (18 $\mathrm{hm}^{3}$ every year).

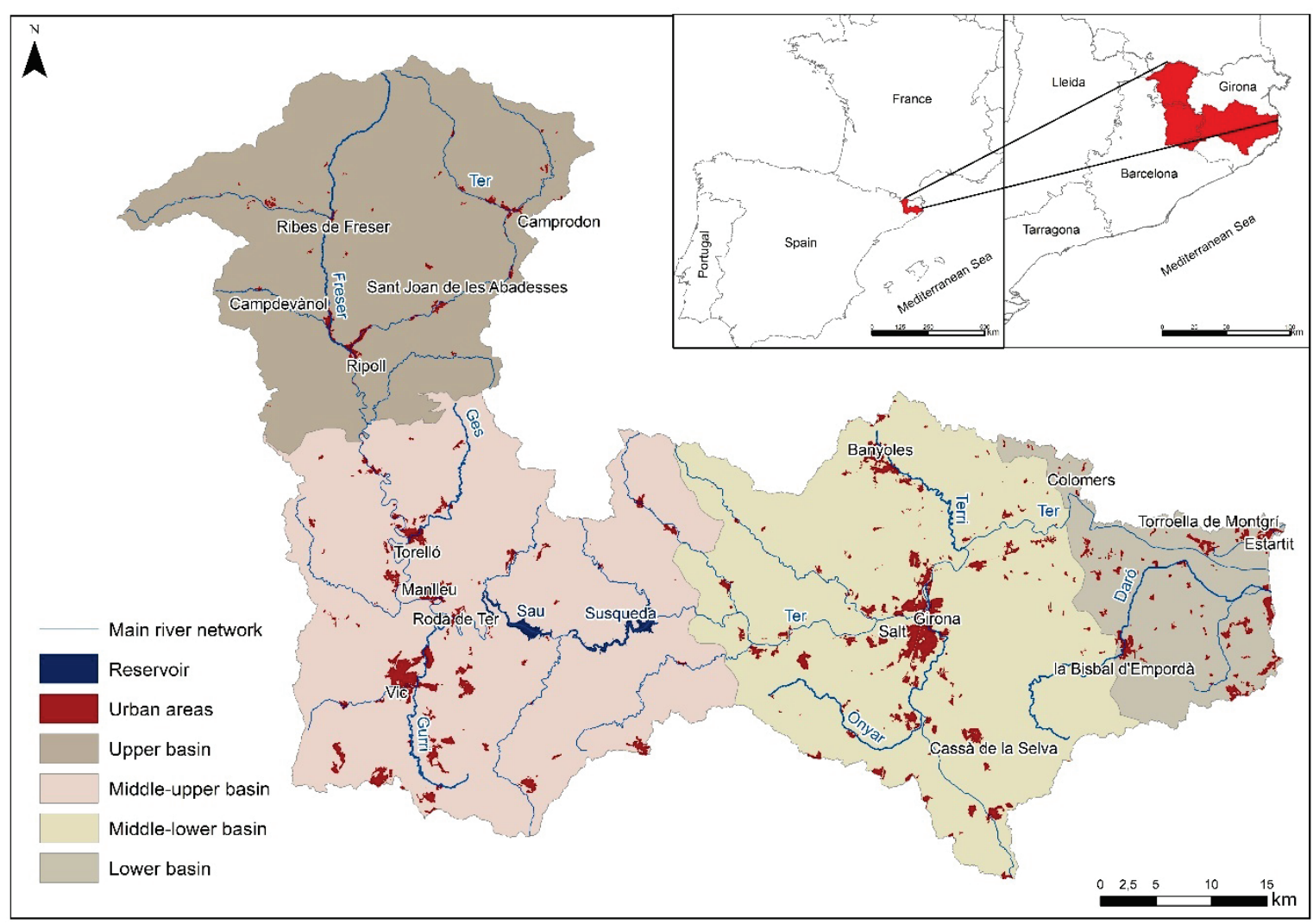

Figure 1. Ter River basin: Main river network, territorial models and urban areas.

From an environmental and socio-territorial point of view four major territorial units may be differentiated in the Ter basin:

1. The Pyrenean valleys of the Upper basin running through the Ripollés region. Historically, these valleys, of a complicated orography, have been sparsely settled with few major centers (Ripoll, Ribes de Freser or Camprodon) but poor communications. In recent years, the steady increase in mountain tourism (Vallter and Núria ski resorts, rural tourism and secondary dwellings) and the creation of protected natural areas (Parc Natural de les Capçaleres del Ter i el Freser) has contributed to a certain demographic and economic dynamism in an area that was severely affected by the crisis of traditional textile and metallurgic production since the middle of the $20^{\text {th }}$ century.

2. The Middle-upper basin comprising the Osona region bounded at its eastern end by the Sau, Susqueda and El Pasteral reservoir complex. Here, the Ter runs through the Plana de Vic, a passageway between the Pyrenees and the Catalan Precoastal mountain ranges. Textile mills, many of them profiting from the hydraulic energy of the Ter and tributaries made this part of the basin an important industrial enclave. Textiles today have lost their competitive edge to food processing industries based on livestock and especially on intensive pig farming. The towns of Manlleu, Torelló and Vic concentrate 90 percent of the population of this unit. 
3. The Middle-lower basin encompassing part of the Selva and Gironés regions, and the southernmost part of Pla de l'Estany region. This is an area of gentle rolling hills and plains home to highly diversified economic activities, from agriculture and livestock to several industrial branches and the specialized services typical of the urban agglomerations. The most important population center in the entire basin, the city of Girona (101,852 inhabitants in 2019) specializes in the service economy (insurance, real estate, public administration, commercial sectors) as well as in urban tourism.

4. The Lower basin including the large alluvial plain of the Ter River and stretching from the southernmost part of the Gironés region and the northernmost part of the Baix Empordà region towards the sea. Irrigated agriculture (cereals, vegetables, rice and fruit trees), in the fertile lands of the interior, and mass tourism on the coast have shaped a very dynamic area, of which Torroella de Montgríl'Estartit is the main center. The Aiguamolls del Baix Empordà, located at the end of the Ter and the Daró rivers, today a natural park, has been the target of various policies for the preservation and restoration of wetlands (LIFE la Pletera, in the area of the Aiguamolls del Baix Ter) and promotion of natural and scenic values (Parc Natural del Montgrí, les illes Medes i el Baix Ter).

\section{Methodology and data sources}

The methodology used in this article is based on the collection and analysis of data and written texts related to episodes of extraordinary floods that occurred in the Ter River basin during the period 1900-2020. The analysis focuses on the three factors that intervene in the impact of floods: exposure, susceptibility and adaptive capacity, according to the framework proposed by the IPCC (2014). The choice of flood episodes is made according to Llasat et al., (2005) who define catastrophic floods as "Precipitation episodes that cause the overflow of river courses and / or the accumulation of water on the surface and cause serious damage to people (victims) and / or property (bridges, buildings, crops, water infrastructure, buildings, factories, shops, etc.)". Following these criteria, we have selected for analysis 9 episodes in total, spread over 4 periods. This temporal division in four periods obeys to changes in the dominant models of territorial organization in the different subareas of the basin. The periods are as follows: 1) from the agroindustrial development of the early $20^{\text {th }}$ century to just before the Spanish Civil War (1900-1935); 2) from the hardship of the war and postwar years to the completion of the Susqueda reservoir (1936-1969); 3) from the transformations brought about by tourism to the consolidation of democracy in Spain (1970-1985), and 4) the final period of intensification of population, urban and tourist growth (1985-2020) (Table 1).

Table 1. Catastrophic floods for different periods

\begin{tabular}{|c|c|}
\hline Periods & Catastrophic floods \\
\hline 1900-1935 & $\begin{array}{c}\text { 7-10 October } 1919 \\
\text { 15-19 December } 1932\end{array}$ \\
\hline 1936-1969 & $\begin{array}{l}\text { 17-20 October } 1940 \\
\text { 11-12 October } 1962 \\
\text { 13 September } 1963\end{array}$ \\
\hline $1970-1985$ & $\begin{array}{l}\text { 11-12 October } 1970 \\
7 \text {-8 November } 1982\end{array}$ \\
\hline $1986-2020$ & $\begin{array}{l}\text { 10-11 October } 1994 \\
\text { 19-23 January } 2020\end{array}$ \\
\hline
\end{tabular}


For the analysis of the magnitude of the selected flood episodes, we have used data of total recorded precipitation; average daily flow $(\mathrm{Qc})$ and maximum registered or estimated flow (Qci). Precipitation data was provided by the Servei Meteorològic de Catalunya (SMC) and local observers. Hydrological data come from the Catalan Water Agency (ACA), the Hydrographic Confederation of the Eastern Pyrenees (CHPO) as well as various technical reports and scientific publications.

For the analysis of population growth in flood prone areas, we have used the population censuses of the municipalities that are part of the Ter basin and provided by the Institut d'Estadística de Catalunya (IDESCAT). The description of the main characteristics and impacts caused by each of the episodes derives from extensive content analysis of local and regional media sources, mainly El Autonomista, Diario de Girona, El Punt Avui, El 9 Nou and La Vanguardia. Memoranda and technical reports of damages caused for the most catastrophic episodes carried out by local, regional (Catalan) and national administrations containing detailed accounts of each episode, inventory of damages, planned reconstruction measures, etc. have been also a valuable source of information (for example, Comisaría General de Regiones Inundadas, 1942; Gobierno Civil de Gerona, 1964 y 1979; Llansó de Viñals, 1971). However, a note of caution should be introduced when presenting economic losses. Most data in this regard is quite heterogeneous and/or insufficient, especially for the oldest episodes. Moreover, studies of the evolution of losses using constant monetary units and studies of normalized economic losses (losses estimated in proportion to the economic wealth of each period) are lacking. Hence, appreciations are highly qualitative and based on aggregated data. We have also used scientific publications derived from research projects on the subject matter and specific plans, projects and maps included in river basin documents, emergency management proposals and the building of flood control infrastructure (Plan of Fluvial Areas of the Baix Ter, Special Plan for Flood Emergencies in Catalonia (INUNCAT), municipal emergency plans, etc.). From these documents two types of information have been obtained. First, data on precipitation, river flows and flood mapping which have helped in characterizing exposure to floods in the study area. Second, data on flood management actions currently existing in the basin have made possible an assessment of current adaptive capacity to this hazard.

\section{Results}

\subsection{Physical characteristics of floods}

The Ter basin has historically registered the largest number of floods in the fluvial basins of Eastern Catalonia, with 135 documented events for the period 1322-2020 (Llasat et al., 2005; ACA, 2018 and updates by the authors). Floods in the Ter are mostly associated with episodes of precipitation of two basic types: First, episodes of short to medium duration (between 6 and 72 hours) with heavy rains lasting several hours and accumulating large amounts of precipitation (200-500 mm). These episodes occur mainly in autumn and sporadically in spring and may generate floods that affect the whole basin or a large part of it. Historically, this is the most important type of flood affecting the entire basin, although the construction of the Sau-Susqueda-el Pasteral reservoir complex in the middle of the $20^{\text {th }}$ century has reduced flood flows downstream of these reservoirs. The second type are more localized episodes of very short duration (less than 6 hours) but of high intensity, such as the one that occurred in L'Estartit in October 1994. These episodes tend to appear during the summer and early autumn and produce mostly local flooding increasingly in coastal areas but can also occur in the upper part of the basin. The latest reports of the Spanish Meteorological Agency (AEMET, 2015), following the calculation parameters of the IPCC (2014), indicate that these local extreme precipitation events tend to be more pronounced and severe in recent decades. Moreover, they produce the so called "pluvial flooding" that is becoming the main type of flood in recent times (Ribas et al., 2020).

Basic data and area affected by catastrophic floods in the Ter basin for the period 1900-2020 are shown in Table 2. These catastrophic episodes concentrated in autumn and usually involved a large part of the basin. Some extraordinary precipitation values (such as the $870.1 \mathrm{~mm}$ of Camprodon in the 
episode of October 1940) are of note. The hydrological response was generally fast since instantaneous maximum flows appeared either the same day or, at the latest, the next day. The most extraordinary peak flows in the Ter River occurred in the episode of October $1940\left(2,350 \mathrm{~m}^{3} / \mathrm{s}\right.$ estimated in Roda de Ter and Girona and 2,400 $\mathrm{m}^{3} / \mathrm{s}$ in Torroella de Montgrí).

Table 2. Catastrophic floods in the Ter River Basin (1900-2020). Precipitation and registered/estimated river flows for different meteorological and gauging stations

\begin{tabular}{|c|c|c|c|c|c|c|}
\hline \multirow[t]{2}{*}{ Episode } & \multirow{2}{*}{$\begin{array}{c}\text { Area } \\
\text { affected }\end{array}$} & \multicolumn{2}{|c|}{ Precipitation $(\mathrm{mm})$} & \multicolumn{3}{|c|}{ River Flow $\left(\mathrm{m}^{3} / \mathbf{s}\right)^{* * *}$} \\
\hline & & $\begin{array}{c}\text { Meteorological } \\
\text { station }\end{array}$ & $\mathbf{P}(\mathbf{m m})$ & Gauging station & $\begin{array}{l}\mathbf{Q c}^{*} \\
\left(\mathbf{m}^{3} / \mathbf{s}\right)\end{array}$ & $\begin{array}{l}\text { Qci** } \\
\left(\mathbf{m}^{3} / \mathbf{s}\right)\end{array}$ \\
\hline 7-10 October 1919 & Basin & $\begin{array}{l}\text { Ribes de Freser } \\
\text { Sant Hilari Sacalm } \\
\text { El Pasteral }\end{array}$ & $\begin{array}{l}347 \\
334 \\
305\end{array}$ & $\begin{array}{l}\text { Ripoll } \\
\text { Roda de Ter } \\
\text { Girona }\end{array}$ & $\begin{array}{l}240 \\
578 \\
\text { n.d. }\end{array}$ & $\begin{array}{c}530 \\
1,100 \\
1,320\end{array}$ \\
\hline 15-19 Decem.1932 & Basin & $\begin{array}{l}\text { Camprodon } \\
\text { Ripoll } \\
\text { Susqueda } \\
\text { Girona } \\
\text { Banyoles }\end{array}$ & $\begin{array}{c}586 \\
332.7 \\
519 \\
428.8 \\
519\end{array}$ & $\begin{array}{l}\text { Ripoll } \\
\text { Roda de Ter } \\
\text { Girona } \\
\text { Torroella de Montgrí }\end{array}$ & $\begin{array}{l}418 \\
863 \\
\text { n.d. } \\
770\end{array}$ & $\begin{array}{c}919 \\
1,800 \\
1,320 \\
1,400\end{array}$ \\
\hline 17-20 Octob. 1940 & Basin & $\begin{array}{l}\text { Camprodon } \\
\text { Ribes de Freser } \\
\text { Susqueda }\end{array}$ & $\begin{array}{c}870.1 \\
375 \\
437.1\end{array}$ & $\begin{array}{l}\text { Ripoll } \\
\text { Roda de Ter } \\
\text { Girona } \\
\text { Torroella de Montgrí }\end{array}$ & $\begin{array}{c}450 \\
1,237 \\
\text { n.d. } \\
1,340\end{array}$ & $\begin{array}{l}1,050 \\
2,350 \\
2,350 \\
2,400\end{array}$ \\
\hline 11-12 Octob. 1962 & $\begin{array}{l}\text { Middle- } \\
\text { lower and } \\
\text { Lower } \\
\text { basin }\end{array}$ & Girona & 190.2 & Torroella de Montgrí & 500 & 900 \\
\hline 13 September 1963 & $\begin{array}{l}\text { Middle- } \\
\text { lower and } \\
\text { Lower } \\
\text { basin }\end{array}$ & Girona & 113.5 & $\begin{array}{l}\text { Ripoll } \\
\text { Roda de Ter } \\
\text { Torroella de Montgrí }\end{array}$ & $\begin{array}{l}223 \\
770 \\
740\end{array}$ & $\begin{array}{c}634 \\
1,300 \\
1,340\end{array}$ \\
\hline 11-12 Octob. 1970 & Basin & $\begin{array}{l}\text { Camprodon } \\
\text { Ribes de Freser } \\
\text { Vilallonga de Ter } \\
\text { Girona } \\
\text { Estartit }\end{array}$ & $\begin{array}{c}166 \\
170 \\
190 \\
202 \\
(24 \text { hours) } \\
137.6\end{array}$ & $\begin{array}{l}\text { Ripoll } \\
\text { Roda de Ter } \\
\text { Torroella de Montgrí } \\
\text { Girona }\end{array}$ & $\begin{array}{c}275 \\
400 \\
620 \\
597.5\end{array}$ & $\begin{array}{c}1,050 \\
1,066 \\
1,100 \\
971\end{array}$ \\
\hline 7-8 Novemb. 1982 & Upper basin & $\begin{array}{l}\text { Ribes de Freser } \\
\text { Susqueda }\end{array}$ & $\begin{array}{c}201 \\
171 \\
\text { (24 hours) }\end{array}$ & $\begin{array}{l}\text { Ripoll } \\
\text { Roda de Ter }\end{array}$ & $\begin{array}{l}550 \\
750\end{array}$ & $\begin{array}{l}1,000 \\
1,300\end{array}$ \\
\hline 10-11 Octob. 1994 & Lower basin & $\begin{array}{l}\text { Torroella de Montgrí } \\
\text { Estartit (Torroella de } \\
\text { Montgrí) } \\
\text { La Bisbal d'Empordà }\end{array}$ & $\begin{array}{c}381 \\
320 \\
(217.18 \text { in } \\
24 \text { hours }) \\
258.6\end{array}$ & Estartit & n.d. & 300 \\
\hline 19-23 January 2020 & Basin & $\begin{array}{l}\text { Ull de Ter } \\
\text { Molló } \\
\text { S. Joan de les Abad. } \\
\text { Sant Pau de Segúries } \\
\text { Embalse de Sau } \\
\text { Viladrau } \\
\text { Girona } \\
\text { Cassà de la Selva } \\
\text { Torroella de Montgrí }\end{array}$ & $\begin{array}{l}214.6 \\
283.3 \\
267.5 \\
402.7 \\
353.5 \\
425.8 \\
242.9 \\
281.3 \\
110.5\end{array}$ & $\begin{array}{l}\text { Ripoll } \\
\text { Roda de Ter } \\
\text { Girona } \\
\text { Colomers } \\
\text { Torroella de Montgrí }\end{array}$ & $\begin{array}{c}311.63 \\
636.54 \\
\text { n.d. }\end{array}$ & $\begin{array}{c}456.73 \\
1,178.80 \\
1,080 \\
1,300 \\
1,000.8\end{array}$ \\
\hline
\end{tabular}

*Daily average flow; ** Maximum recorded flow; *** Average annual flows since the completion of the Susqueda reservoir (in $\mathrm{m}^{3} / \mathrm{s}$ ): Sant Joan de les Abadesses (6.41), Ripoll (9.8), Roda de Ter (17.15), El Pasteral (10.82), Girona (13.63), mouth (26.6). Source: Consorci del Ter and Fundació AGBAR (2004). Own elaboration from Servei Meteorològic de Catalunya (SMC) and local observers (precipitation) and Agència Catalana de l'Aigua (ACA) (river flows) 


\subsection{Exposure}

In the Ter basin, exposure to floods has been increasing during the last century. Population growth and agricultural, industrial, and especially urban expansion in flood prone areas appear to be the main causal factors. Between 1900 and 2019 the population of the Ter basin has more than doubled, growing from 177,000 to 454,000 inhabitants (Table 3 and Figure 2). The increase in urban density and its configuration along the Ter River and its main tributaries has led to a progressive concentration of the population in urbanized floodplains. While in 1900, half of the population concentrated close to the Ter and its tributaries, in 2019, almost three quarters of the population of the basin lived in these areas.

Table 3: Population change in the Ter sub-basins (1900-2019)

\begin{tabular}{lccccc}
\hline & Upper Basin & $\begin{array}{c}\text { Middle } \\
\text { Upper Basin }\end{array}$ & $\begin{array}{c}\text { Middle lower } \\
\text { basin }\end{array}$ & Lower basin & Total \\
\hline 1900 & 25,974 & 59,216 & 69,496 & 22,885 & 177,571 \\
1910 & 27,677 & 62,201 & 74,769 & 23,983 & 188,630 \\
1920 & 29,220 & 66,679 & 78,664 & 23,897 & 198,460 \\
1930 & 29,907 & 72,353 & 86,392 & 23,233 & 211,885 \\
1940 & 27,364 & 71,331 & 93,343 & 22,413 & 214,451 \\
1950 & 29,319 & 74,595 & 95,309 & 22,878 & 222,101 \\
1960 & 30,821 & 83,368 & 105,912 & 23,397 & 243,498 \\
1970 & 30,220 & 96,645 & 129,101 & 26,010 & 281,976 \\
1981 & 29,445 & 106.653 & 175,927 & 26,837 & 338,862 \\
1991 & 26,938 & 108,675 & 162,515 & 28,171 & 326,299 \\
2000 & 26,121 & 114,986 & 175,008 & 31,718 & 347,833 \\
2010 & 26,580 & 138,890 & 228,462 & 39,883 & 433,815 \\
2019 & 25,087 & 146,179 & 243,095 & 40,072 & 454,433 \\
\hline
\end{tabular}

Own elaboration from IDESCAT

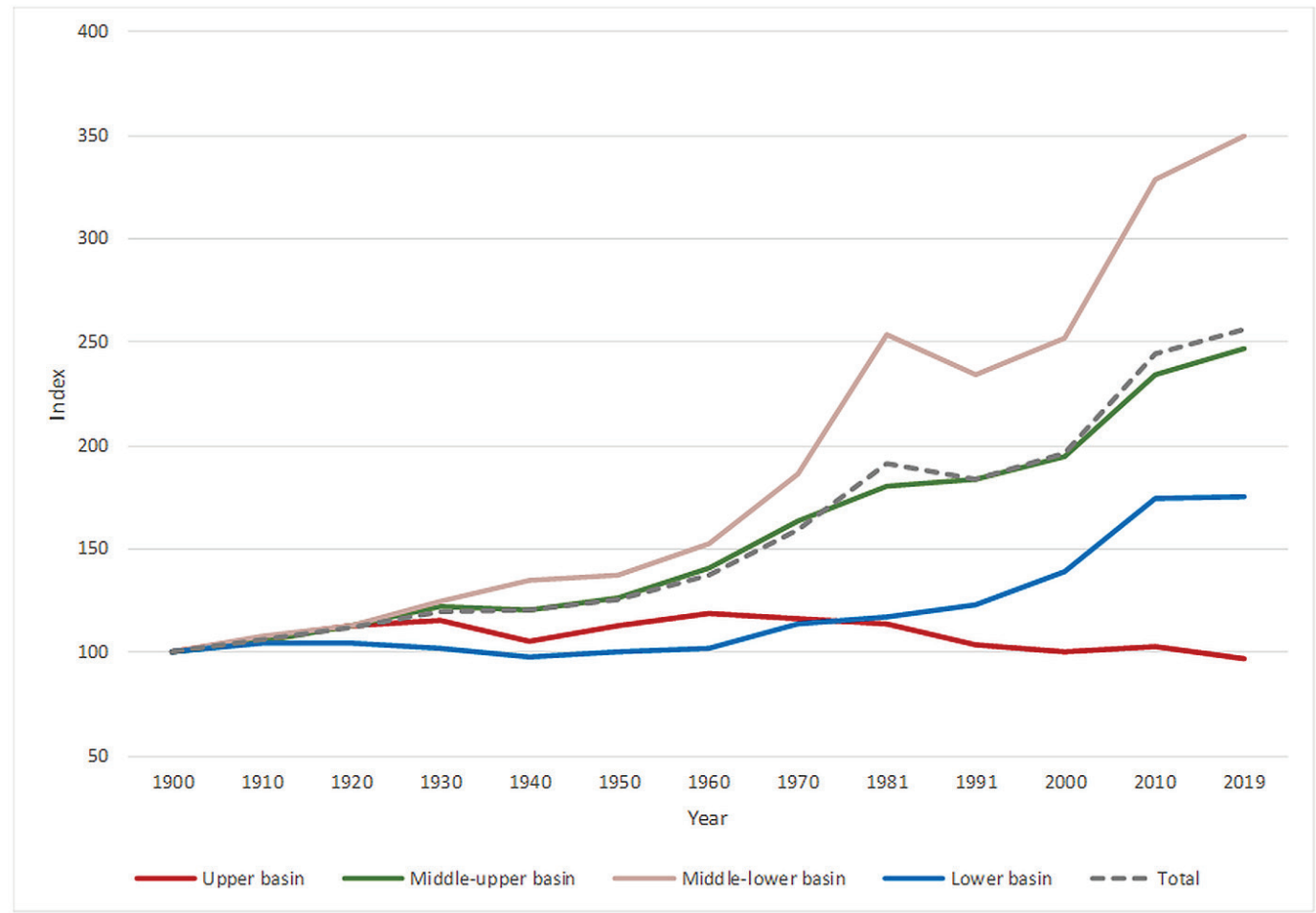

Figure 2. Population change in the Ter River Basin 1900-2020. Total and sub-basins $(1900=100)$. Own elaboration from IDESCAT data 
However, population, industrial and urban growth is also characterized by notable spatial and temporal differences. As in the rest of Catalonia, the first third of the 20th century was marked by the intensity of the industrialization and urbanization processes in the upper and middle basin where numerous textile mills took advantage of the hydraulic resource potential of the river and tributaries. Metal works, paper and tanneries, and hardware proliferated in towns such as Ripoll, Torelló, Manlleu and Girona. In the lower basin, the crisis brought about by the philoxera pest that ruined vines in Catalonia damaged the important cork industry of the area while agricultural development remained limited. On the other hand, however, the road and railway networks expanded improving considerably communications with Barcelona and France as well as communications along the river course.

The economic and social crisis caused by the Spanish Civil War and the post-war period severely affected industrial occupation and slowed rural exodus, so that demographic and urban growth until the late 1950s was weak in most of the basin. The 1940s and 1950s were thus characterized by slow or stagnant economic growth although some sectors (especially textile centers) could benefit from their privileged position within the Spanish autarchy system. The strategic change of the Spanish economy abandoning autarchy and embracing liberalization and openness at the end of the 1950s inaugurated an era of rapid economic growth in Catalonia which again translated into population, industrial and urban expansion in the Ter basin. Fueled by migration from Southern Spain, population in the basin grew from the 243,000 inhabitants in 1960 to 338,000 in 1981; that is, an increase of almost $30 \%$ in 20 years. Growth, however, was uneven. Demographic and economic stagnation began to extend in the upper basin where traditional manufacturing was hit hard by the crisis and restructuring of textiles. In the rest of the basin the industrial base diversified from textiles to new sectors, especially food processing, and metallurgical and chemical production while mass tourism expanded along the coast. The 1970s brought about the definitive crisis for the textile sector along with the closure and abandonment of many mills located in the main river courses, especially in the upper and middle-upper basin. Cities such as Vic, Girona and Banyoles survived the crisis by reinforcing the specialization in food processing and above all by a strong shift towards the service economy. On the other hand, the definitive specialization of the lower basin in mass tourism insulated the area from the effects of economic restructuring during this period at the expense however of a rapid and intense occupation and transformation of flood prone land.

The 1990s and especially the entry of the 21 st century, inaugurated a new stage of demographic and urban growth. The process of population concentration in the main urban centers located along the Ter River and their areas of influence continued to increase. In the upper and middle basin, about three quarters of the population is concentrated in a few municipalities, most of them close to the river or tributaries. In the lower basin, two municipalities absorb about half of the population, but others on the coast see their numbers increase exponentially during summer. Beyond any doubt, tourism has been the main activity driving the economy of most of the basin. In the upper basin snow and mountain tourism has taken the role previously played by textile mills as the economic engine while in the lower basin sun and beach tourism is by far and large the dominant activity. Specialization in tourism and its different modalities has led to the proliferation of secondary dwellings, campsites, hotels, rural tourism houses and other tourist infrastructures and facilities, which have contributed to revitalize the stagnant economy of the upper basin and feed the expanding economy of the lower basin. Nevertheless, the expansion of tourism, urbanization and related infrastructures in floodplains and coast lines has also meant an increase in the exposure of people and goods to inundation. The construction of increasingly large and complex infrastructures and facilities (distribution centers for basic services such as water, energy, gas or telephones, distribution and logistics centers, fire stations, etc.) often located in flood prone areas and frequently affected by episodes of river flooding or by heavy rainfall represents perhaps the most visible example of this increasing exposure to floods.

To summarize this historical overview on exposure in the Ter River basin, it is estimated that the land to be flooded by events with a return period of 500 years is approximately 15,230 hectares (ha) or 4.65 percent of the total area of the basin, of which urban land represents 1,480 ha or 10 percent of 
the total land at risk of flooding. This figure is below the Catalan average estimated in 15 percent (Vilaplana, 2008; Saurí, 2011) (Table 4). The largest flood prone area is in the alluvial plain of the Ter River, in the middle-lower basin (5.16 percent of the total area is at risk of flooding) and the lower basin (about 25 percent at risk of flooding). Except for the cities of Girona, la Bisbal d'Empordà and Torroella de Montgrí-l'Estartit and their peripheries, most of the area potentially affected by flooding is agricultural land. Urban land in areas at risk of flooding is larger in the upper and middle-upper parts of the basin (between 21 and 25 percent of the total) than in the middle-lower part (between 8 and 10 percent) and the lower part (between 3 and 5 percent), which is explained by the higher urban densities along the Ter River and its tributaries found upstream of the reservoir system.

Table 4. Land use zoning for areas exposed to the 500-year flood. Ter River basin 2019

\begin{tabular}{|l|c|c|c|c|c|c|c|c|c|c|}
\hline Land Use Category & $\mathbf{1}$ & $\mathbf{2}$ & $\mathbf{3}$ & $\mathbf{4}$ & $\mathbf{5}$ & $\mathbf{6}$ & $\mathbf{7}$ & $\mathbf{8}$ & $\mathbf{9}$ & $\mathbf{1 0}$ \\
\hline $\begin{array}{l}\text { Urban } \\
\text { (consolidated) }\end{array}$ & $1,129.7$ & 7.42 & 181.14 & 22.73 & 369.61 & 20.29 & 367.2 & 6.85 & 211.6 & 2.92 \\
\hline $\begin{array}{l}\text { Urban } \\
\text { (non-consolidated) }\end{array}$ & 53.6 & 0.35 & 10.69 & 1.34 & 26.49 & 1.45 & 9.12 & 0.17 & 7.29 & 0.10 \\
\hline $\begin{array}{l}\text { Programmed urban } \\
\text { (marked) }\end{array}$ & 247.4 & 1.62 & 20.26 & 2.54 & 85.01 & 4.67 & 95.3 & 1.78 & 46.7 & 0.65 \\
\hline $\begin{array}{l}\text { Programmed urban } \\
\text { (non marked) }\end{array}$ & 39.3 & 0,26 & 1.86 & 0.23 & 5.59 & 0.31 & 15.06 & 0.28 & 16.77 & 0.23 \\
\hline $\begin{array}{l}\text { Non-urban } \\
\text { TOTAL IN Q500 }\end{array}$ & $15,230.3$ & 100 & 796.95 & 100 & $1,821.6$ & 100 & $5,357.7$ & 100 & $7,253.9$ & 100 \\
\hline TOTAL AREA (ha) & 328,174 & 4.64 & 82,530 & 0.97 & 112,443 & 1.62 & 103,731 & 5.16 & $29,470.1$ & 24.61 \\
\hline
\end{tabular}

$1=$ area (ha); 2 = Percent within the 500 yr. flood; 3 = Upper Basin (ha); 4 = Percent within the 500 yr. flood; $5=$ Middle Upper Basin (ha); $6=$ Percent with in the 500 yr. flood; $7=$ Middle Lower Basin (ha); $8=$ Percent within in the 500 yr. flood; $9=$ Lower Basin (ha); $10=$ Percent within the 500 yr. flood.

Own elaboration from ACA (for the determination of the $500 \mathrm{yr}$ flood) and Departament de Territori i Sostenibilitat de la Generalitat de Catalunya (for land use categories).

\subsection{Susceptibility}

In this article two main types of susceptibility to floods are singled out: human and social susceptibility, related to factors that may intervene in the loss of human lives, and functional and economic susceptibility, related to the characteristics of the different socioeconomic activities that may influence the possibilities of suffering damages. Human and social susceptibility depend both on the magnitude of the event and on intrinsic (age, income, gender, perception, knowledge, physical capacities of individuals, etc.) and extrinsic (effectiveness of protection/prevention measures, capacity for recovery, etc.) characteristics of people exposed. Functional and economic susceptibility is related to the various socioeconomic activities present in affected areas. It depends on the level of damage to economic activities, property, infrastructures, and the capacity of society to restore the normal operation of interrupted or disturbed activities.

\subsubsection{Human and social susceptibility}

One remarkable finding in the characterization of flood impacts in the Ter basin is the very low number of catastrophic episodes with human victims. In fact, of the nine episodes selected for analysis only one that of October 1940, stands out in terms of human deaths while the rest (except for one death in the episode of 1932) do not register human casualties. This is rather unusual in the recent history of 
flood events in Catalonia and Spain where a consistent reduction in the number of human victims caused by floods in the last decades does not rule out a certain number of deaths even for relatively small episodes.

At any rate, deaths caused by floods of the Ter and its tributaries have occurred mostly in the homes themselves, where people drown, are swept away by the flow or are crushed by rubble provoked by crumbling walls and roofs. This was the norm in historical episodes such as those caused by the Galligants River in Girona (September 18 and 19, 1843, approximately 115 human victims) or the Mèder in Vic (8th of October 1863, a hundred dead). As said, for the period studied, the episode that caused the largest number of human victims was the so called "Aiguat de Sant Lluc" (October 17-20, 1940), with some 80 deaths in the Ter basin, 61 of which in Torelló, 10 in Manlleu (in the middle-upper basin), and the rest in Girona (Table 5).

Table 5. Documented human and economic losses

\begin{tabular}{|c|c|c|c|}
\hline $\begin{array}{c}\text { Episode } \\
\text { (year) }\end{array}$ & Human victims & $\begin{array}{c}\text { Economic losses* } \\
\text { (Ter Basin) }\end{array}$ & $\begin{array}{c}\text { Economic losses* } \\
\text { (Girona province) }\end{array}$ \\
\hline 1919 & 0 & $\begin{array}{c}30.700 \text { PTA } \\
\text { in the town of Verges } \\
\text { (agriculture) }\end{array}$ & n.d. \\
\hline 1932 & 1 (Girona) & n.d. & n.d. \\
\hline 1940 & $\begin{array}{c}80 \\
\text { (71 in Manlleu } \\
\text { and Torelló and } \\
\text { the rest in } \\
\text { Girona) }\end{array}$ & 0 & 150 million PTA PTA \\
\hline 1962 & 0 & Muga basins). \\
\hline 1970 & 0 & 500 million PTA in Girona & 162 million PTA \\
\hline 1982 & 0 & 900 million PTA & 600 million PTA \\
\hline 1994 & 0 & n.d. & n.d. \\
\hline 2020 & & $\begin{array}{c}\text { Girona and Torroella de } \\
\text { Montgrí-Estartit) }\end{array}$ & 100 million euros \\
\hline
\end{tabular}

* Losses in PTA (peseta was the name of the Spanish currency before 2002). Losses correspond to PTA of each year and are not corrected for inflation.

Own elaboration from technical reports and memoranda, and press clips.

The analysis of who died in this episode reveals the importance of housing characteristics (location, quality of construction, state of conservation, etc.) which, in turn, are closely related with wealth. Most of the people who died in Torelló and Manlleu were low income residents who lived in old housing located near the river built with generally low-quality materials (earthen walls) and therefore highly susceptible to the ravaging effects of floodwaters. However, in Girona, most of the deaths were caused by the collapse of a bridge where many people had concentrated to watch the flood wave of the Güell River. Human negligence and the failure of authorities to prevent such risky behavior were already a factor which will become more important in the following decades. In conclusion, mortality caused by floods of the Ter and its tributaries during the period of study is concentrated almost exclusively on the single catastrophic episode of October 1940, the most important in terms of rainfall and flows recorded in the basin, and which took place right after the end of the Spanish Civil War under very difficult social and economic conditions for most of the population in the basin.

However, human and social vulnerability increases significantly in some of the catastrophic episodes analyzed, considering the number of people affected, either because they have suffered physical impairment (injuries, mental illnesses) or because they have lost part or all of their properties. 
In episodes such as those of 1940 or 1962, social inequalities strongly influenced the susceptibility of different social groups and their limited responses to the flood. Thus, many of those affected by the 1940 episode were industrial workers in factories located in towns such as Ripoll, Manlleu, Torelló, or Salt, that lost their jobs (Ribas and Saurí, 1993). In the 1960s, when it was necessary to build new housing in Campdevànol for groups with low purchasing power, two blocks of houses for this purpose were built in an area flooded by the 1940 episode (Codinachs, 1994). Another example is the more than 500 immigrants, mostly from Andalusia, who had to leave the "Río" neighborhood in Girona, after the flood of October 1962 devastated the self-built shacks occupying the same bed of the Ter River (Ribas, 1994). In all these cases, the need to ensure a facility as basic as housing explains the occupation of flood prone spaces, that is, spaces where the value of the land was low or simply zero.

\subsubsection{Economic and functional susceptibility}

In general terms it can be argued that, for the whole of the Ter River basin, economic and functional susceptibility to floods exceeds, in economic terms at least, human and social susceptibility. Although we are not able to express figures of economic losses in constant values, Table 5 reflects a tendency towards an increase in the amount of economic losses in each new catastrophic flood episode analyzed. However, the levels of economic and functional vulnerability vary depending not only on the magnitude of the episodes but especially on the degree of impact and recovery capacity of the economic activities and infrastructures characteristic of each territorial model for each historical period.

During the first part of the study period (1900-1935), two clearly differentiated models of territorial organization can be identified: an agrarian-based model in the lower basin and an agroindustrial model combined with urban-services in the rest. In the lower basin, agriculture is the most susceptible productive sector of the period. The floods of 1919, and especially 1932, destroyed much of the cereal and fodder crops of the alluvial plain and caused severe damage to riverbank tree plantations. Irrigated infrastructures (Sentmenat canal and the Canet protection wall) were especially affected and some towns remained isolated for days due to damages to roads and highways. The rapid reconstruction of impaired irrigation infrastructures and the management of changes in course and direction experienced by the riverbed that occurred after each flood would be the most important demands raised by farmers since these impacts often meant the interruption of production cycles for more than one year. The conservation of traditional forms of settlement in the highest elevations of the floodplain would explain the low impact of floods on homes and buildings (Saurí et al., 1993).

The agro-industrial model, combined with the urban/service economy of the rest of the basin, explains why industry and services were the most affected economic sectors in this period. Since the end of the 19th century and into the first third of the 20th, the Upper, Middle-upper and Middle-lower sub-basins saw the installation of factories and industrial estates and the development of the road network (roads and railways). Consequently, hydroelectric power plants, factories, and industrial channels in towns such as Ripoll, La Farga de Bebié or Bonmatí were heavily affected by the episodes of 1919 and 1932. Also, railway, bridges, roads and highways were hit by landslides. Cities such as Manlleu, Girona or Banyoles, which during these years experienced significant urban development, also suffered high damages to industries, shops and urban services, such as the electricity supply.

The Spanish Civil War represented the starting point of a context of great economic precariousness that will characterize much of the second period under study (1936-1969). In a context of post-war economic and political crisis, economic and functional susceptibility to floods grew throughout the basin. Autarchy and interventionism inspired economic policy in the early years of the Franco government and reverted into minimal capital investment in the industrial base of the Ter basin which, on the other hand, had experienced a considerable dynamism between 1914 and 1936. With the industrial base reduced, agriculture and informal tertiary services became refuge activities for a depauperated population. It is in this context that on October 17 and 18, 1940, one of the most 
catastrophic floods in the history of the Ter River took place, attributable not only to rainfall amounts of a "monsoon" intensity (around 1,000 $\mathrm{mm}$ in 24 hours in the Vallespir region), but especially to the economic and social context of the period. In total, in the Girona province, 90 deaths, 58 destroyed bridges, 25 kilometers of seriously damaged roads, damages to 165 industries, 149 businesses, 230 urban farms and some 174,192 flooded hectares of cultivation were recorded. Economic losses at that time were valued at 120 million pesetas, an exorbitant figure for the period (Ribas and Saurí, 1993). Industrial activity was one of the most affected sectors. Many of the yarn and knitwear textile factories, metallurgical workshops, food processing factories, etc. in towns such as Torelló, Manlleu, Ripoll, Roda de Ter, Angles or Salt, but also many of the dams and canals that made possible the production of the energy necessary for their operation, were seriously impaired and many of the workers were left unemployed. Damages of the built environment were extensive in Girona due to the combined effects of the Ter and its tributaries Güell and Onyar. In the lower basin, the river broke levees at various points and tried to recover its old course, joining its waters with those of the Fluvià River. Material losses concentrated in crops and livestock.

However, the high economic and functional susceptibility of the Ter basin during this episode was not only translated into severe damage to economic activities, properties, infrastructure, but also reflected to the low capacity of society at the time to restore in time interrupted or disturbed activities. Damaged hydraulic control works were rebuilt, but no new flood control infrastructure was constructed or plans preventing the continued use of floodplain areas approved.

The economic and social context of the Ter basin began to change in the second half of the $20^{\text {th }}$ century, following a process of rapid transformations, lacking, however sufficient resources and democratic governance. These transformations accentuated the differences between a traditional agroindustrial model in decline (especially in the upper basin) and an urban/tourism/services model that was gaining prominence in the middle and lower basin. Immigrants from Southern Spain continued to arrive in large numbers occupying flood prone areas of the expanding cities. It is in this context of urbanindustrial expansion that up to 11 flood episodes were registered in the Ter basin in the 1960s, two of them catastrophic (October 11 and 12, 1962; September 13, 1963). Both episodes affect most the Middle-lower and Lower basins, especially the city of Girona and its neighborhoods of Sant Narcís, Santa Eugenia de Ter or Río built on the very same bed of the river Ter (1962). Workshops, warehouses, factories and shops, and water and electricity facilities suffered the greatest impacts. The lower basin, which until the late 1960s maintained a distinctive agrarian model, also suffered from the effects of these episodes. Floods occurred almost every year in the 1960s causing serious inconveniences to agriculture and livestock, as well as damages to roads and highways. The persistence of the problem of floods during this period of strong economic development and increases in the standard of living explains the repeated complaints and demands of farmers, commercial interests and local administrations (from the municipalities to the provincial councils) for the construction of flood control works in Ter and its tributaries, but especially for the construction of the long promised reservoirs in the middle section of the river.

The inauguration of the Susqueda reservoir in 1969 marks a turning point regarding flood control in the Middle and Lower basin. Reservoirs exerted an unquestionable containment effect on floods downstream which explains the decline in episodes during the 1970s. In the period 1970-1985 there were two catastrophic flood episodes (October 11 and 12, 1970; and November 8, 1982) both exemplifying the changes in exposition and susceptibility derived from the territorial refunctionalization of the Ter basin, especially in the Lower and Upper basins, brought about by tourist activities. In the Upper basin, tourist activities occupied and transformed flood prone areas previously under extensive land uses such as cattle grazing. The flood of November 1982 hit especially hard ski resorts, campsites, weekend and vacation homes, and the burgeoning urban commercial sector of the Upper basin. Together with agriculture, which remained strong especially in the Middle and Lower basin, tourism suffered the largest materials losses of this period. On the coast, the rapid and intensive urban growth of l'Estartit through new residential areas (Griells, la Pletera, Salats), campsites (Delfín 
Verde, la Sirena, etc.) and golf courses (Gualta and Pals) often on flood prone land, explained the dramatic increase in flood losses that will continue in the following decades.

However, the most catastrophic episode of this period affected the city of Girona. In this episode, however, the Ter River only played a secondary role, since the Sau-Susqueda-el Pasteral reservoir complex was able to contain successfully floodwaters from upstream. Two small rivers in the city, the Onyar and the Güell, were the main causes of a flood that inundated more than 75 percent of Girona. Although no deaths were recorded, economic losses were the highest in the history of the city. The most distressed sectors were industrial and commercial establishments. In total, 2,000 of these establishments were damaged with losses amounting to 85 million pesetas. Public services (gardens, drinking water infrastructure, schools, hospitals, etc.) also experienced extensive impacts. Houses and buildings in the flooded area were also hit as were roads and streets and the flood walls of the two rivers. In addition, the flood damaged or ruined about 500 vehicles.

In the 1980s, the Ter basin continued to suffer catastrophic flood episodes, without human victims, but with high economic losses and extensive disruption of normal activities. The 1990s were marked by the episode of October 10 and 11, 1994, which concentrated in the tourist center of l'Estartit, and aggravated by landslides that destroyed residences, hotels and roads. On this occasion, the cause was not the Ter itself but the intense rainfall that fell on the Northern coast of Catalonia. This "pluvial" flood was already interpreted at that time by local meteorologist Josep Pascual as a clear example of change in precipitation patterns in the Mediterranean coast that appeared to indicate an increase in high intensity events (Pascual, 2005). L'Estartit is also a manifestation of a rapid increase in exposure to the risk of flooding after the continuous occupation of the Ter floodplain for tourist related infrastructures and services. However, the town has managed to mitigate relatively rapidly the negative consequences of flooding, and the rate of flood losses appears to fall behind the rate of economic growth. In other words, the level of wealth generated in coastal floodplains may revert to a decrease in vulnerability to floods (Ribas and Serra, 2009).

Finally, the storm Gloria of January 2020 illustrates the susceptibility of productive sectors and infrastructures increasingly linked to tertiary activities and services and public infrastructures, which have gained prominence throughout the basin. In the upper Ter, towns historically hit by floods such as Ripoll and Vallfogona del Ripollès suffered the worst consequences of the event, with damages to roads and railways, water supply systems, sports halls and urban infrastructure. In the Middle upper basin, the most important damages were on the railway line in the Vic-Ripoll section and on local roads as well as on water treatment plants that left towns like Manlleu without drinking water during hours. However, the most important damages occurred in the Middle-lower and lower basins, where the flood forced the population of 26 municipalities to be evacuated or confined.

In the Middle-lower basin, the city of Girona had to deal with the overflow of the Ter, causing important damages to public infrastructures and facilities (sports halls, football fields, schools, the city hospital, the auditorium), electricity supply systems and drinking water networks, urban furnishings, and communications. As a novelty compared to previous episodes, promenades and urban and periurban green infrastructures on the riverbanks that in recent years had been conditioned as leisure areas for hikers and cyclists, were also impaired. In the lower basin, besides the persistent impacts on roads, floods also damaged the highly technified agriculture of fruit orchards and its supporting infrastructures (irrigation channels, access roads, etc.), as well as campsites, promenades and beaches. The flooding of the drinking water treatment plant meant that the towns of Torroella de Montgrí and l'Estartit lacked potable water for three weeks.

In the coastal municipalities of the lower basin, the floods of 1994 and 2020 encountered a population less susceptible to the impacts of extreme events due to higher levels of public and private wealth which facilitated a quicker recovery from losses compared to previous episodes. In the lower Ter, where the storm Gloria harmed some 12,000 hectares of agricultural land, especially cereals and apple trees, aid packages and low-interest loans to farmers from contingency funds were rapidly 
implemented. Similar circumstances occurred in localities hit by the storm Gloria, such as the city of Girona or l'Estartit, where the municipality assumed, in the first instance, the expenses derived from the cleaning of river courses and beaches in order to restore them as soon as possible. Applications for aid were subsequently processed to the regional and national governments to cover for the damages caused.

\subsubsection{Adaptive capacity}

Along with the important territorial transformations experienced by the Ter basin and the impacts of the catastrophic floods that occurred during our period of analysis, adaptation to floods has also changed. Traditional adaptation had usually consisted in avoiding flood-prone land for permanent settlement, and, in fact, this form of adaptation prevailed in the lower basin well into the 20th century. Population settlements tended to locate on river terraces or in the foothills of the Montgrí mountain and away from the alluvial plain (Barbaza, 1988). The construction of lateral earthen levees remained until the mid-20th century the only major hydraulic infrastructure designed to protect farmland from river flooding. After the catastrophic floods of 1919 and 1932, the local authorities of the lower basin requested the embankment of the Ter and the Daró rivers, to protect agricultural land and road infrastructures. By way of example, after the flood of 1919, the Ter Municipal Association was created, bringing together all the riverside municipalities of the Middle-lower and Lower basin, to claim the embankment of the Ter from the Pasteral area to the sea, which has not been implemented (Saurí et al., 1993).

In the rest of the basin, the agro-industrial model combined with the urban/services model had already facilitated the installation of factories, industrial estates and permanent population settlements in the vicinity of the river courses. Therefore, the biggest economic and material losses from catastrophic episodes were from buildings and industrial and urban infrastructures. This would explain why projects and actions to control flooding appear relatively early in the period.

Table 6 includes the main hydraulic infrastructures built in the Ter basin. The flood of October 1940 caused a rapid reaction by the Francoist authorities. The General Directorate for Flooded Regions was created to plan and execute post-disaster recovery actions. However, the economic precariousness of the moment and the lack of flood planning and management policies implied at best, just the reconstruction of hydraulic infrastructure that had been damaged (Ribas and Saurí, 1993). It was not until the 1960s that the persistence of the problems and a greater financial capacity by the state made possible the construction of large flood control works, among which the Susqueda reservoir (1969) and the opening of a new channel for the Daró River in the lower basin. The floods of October 1970 also motivated the materialization of many flood control infrastructures in Girona (Ribas, 1994, 2007 and 2009). The 1982 floods in the upper basin, led to the construction of containment dykes at the headwaters of the Ter, designed to protect population centers downstream. Since the mid-1980s, no major new hydraulic works have been built in the Ter basin, despite the fact that these are often demanded by the population and local councils to regional and national authorities (Roset et al., 1999). Pending projects, such as the construction of reservoirs in the headwaters of the Onyar River in Girona, have to face not only budgetary restrictions but also a certain change of perspective on the problem of flooding inspired by the principles of the European Directive on Floods (Directive 2007/60/EC). The Directive recognizes that floods are impossible to eliminate and, therefore, that societies must learn to "live with them" (Olcina et al., 2016). Both because of European mandates and for financial constraints, the Catalan Water Agency appears to be embracing these new perspectives on flood management. 
Table 6. Main flood control infrastructures in the Ter River basin (1900-2020).

\begin{tabular}{|l|c|c|}
\hline Flood control infrastructure & Location & years \\
\hline Sau Resevoir & Middle upper basin & $1949-1963$ \\
\hline Embankment of the Ges River (Torelló) & Middle upper basin & $1946-1956$ \\
\hline Diversion of the Daró River from Gualta until the Ter River & Middle upper basin & $1963-1968$ \\
\hline Susqueda reservoir & Middle lower basin & $1963-1966$ \\
\hline Channelization of the Onyar River (Girona) & Middle lower basin & $1964-1968$ \\
\hline Diversion and channelization of the Güell River (Girona) & Middle upper basin & $1968-1987$ \\
\hline Flood walls of the Ter River (Manlleu) & Middle lower basin & $1970-1971$ \\
\hline $\begin{array}{l}\text { Dredging and embankment of the Onyar River (Girona) } \\
\text { Lower basin }\end{array}$ & 1970 \\
\hline $\begin{array}{l}\text { Eolomers reservoir } \\
\text { Daró confluence until the sea } \\
\text { Le Freser, Campdevànol, Ripoll, Setcases, etc.) }\end{array}$ & \begin{tabular}{l} 
Lower basin \\
\hline
\end{tabular} & $1971-1973$ \\
\hline
\end{tabular}

Own elaboration

Other measures, such as land use planning in floodplains have proven to be difficult to implement. Urban planning prevailing in municipalities during the Franco years ignored the regulation of land uses in floodplains. With the advent of local elections in the late 1970s, the first urban plans aimed at a certain but still timid, control of growth in these areas. Urban development laws promulgated by the Catalan government have incorporated the risk of flooding as an element to be taken into account in the zoning of new uses in municipal plans. The decade of the 1990s was prolific in the elaboration of cartographies of flood risk by the ACA that are of mandatory consultation in local urban planning. However, the actual implementation of these policies has not always been positive, and areas subject to flooding either from river flows or from rainwater continue to be occupied and transformed. The situation is further complicated in spaces coveted by new urban or tourist developments in some parts of the Ter basin (especially the upper and lower basins). Fortunately, more and more examples can be found in the opposite direction. In recent years, the LIFE Pletera project has been implemented in l'Estartit (one of the towns most exposed to floods and storm surges). This project involved the deurbanization of flood prone land and the restoration of the previous wetland system (Pueyo-Ros et al., 2017 and 2018). Restored wetlands were able to absorb flooding during the Gloria episode of January 2020.

Throughout the study period it can be noticed how post-catastrophe aid is increasingly assumed by public institutions. In the aftermath of the disaster, this aid usually came from spontaneous charity campaigns as well as from local and regional public authorities. Relief Boards were created in order to coordinate immediate assistance and, subsequently, commissions in charge of assessing damages were also established. In the medium and long term, and especially for those episodes with greater impacts, aid was increasingly the responsibility of national institutions, either by enacting enabling financial measures (exemption or moratoria on the payment of taxes, low or no interest loans, etc.) or through direct compensation packages or the coverage of expenses associated with the reconstruction of public services and infrastructures. Laws intended for very extreme events have used the legal figure of "catastrophic zones" by which all public and private losses are assumed by the state. Furthermore, in Spain, the creation in 1954 of the Consortium for Insurance Compensation (Consorcio de Compensación 
de Seguros) guarantees practically universal coverage for floods and other natural risks. The Consortium allows for a minimum of security regarding the recovery of losses caused by floods, which contributes to reducing the relevance of these losses in times of economic difficulties. The evolution of the amounts paid by the Consortium during the last decade indicates not so much an increase in the frequency and impacts of extreme natural phenomena as a greater penetration of insurance and, above all, an increasing accumulation of goods and services in areas of risk (Saurí, 2011). For example, in the Ter basin, the episode of intense rains in June 2000 in the city of Girona generated losses of around 3 million euros in insured damage, including damage to 200 shops and offices, 250 homes and 125 cars (Ribas et al. 2020).

Forecasting and warning systems on extreme precipitation and floods have improved enormously during the period of study, hand in hand with continuous technological progress and greater organizational capacity and availability of human and material resources to deal with emergencies. In the Ter basin emergency management in the event of a flood episode is based on both collective and individual behavior and practice of people living in flood prone areas and from the practices planned by local and regional administrations. During much of the 20th century, solidarity mechanisms and the transmission of knowledge between generations on the precautions to be taken under the threat of a flood (church bells ringing to warn of imminent danger, construction of walls at the entrance of houses to prevent the penetration of water, the transfer of the most valuable belongings to the upper floors of the buildings, etc.) turn out to be many times sufficient for less catastrophic events. In cities like Girona, recurrently hit by floods, some of these individual and collective emergency management systems were certainly useful. For example, since at least the eighteenth century, inhabitants of the lower areas of the old town built doors through dividing walls between buildings at the height of first floors, so that people could move from one building to another and escape danger in times of flooding (Ribas, 1994 and 2009). This peculiar emergency action lasted in Girona until the middle of the $20^{\text {th }}$ century.

Flood warnings from upstream the rivers were practically non-existent until the beginning of the 1930s when the use of the telegraph and telephone became widespread (Díaz, 1989). Since the 1970s these systems have undergone significant progress. Flow and precipitation measurement equipment was extended and improved (the entry into operation of the Sau and Susqueda reservoirs in the 1960s made available information on flow rates upstream of Girona), and the number of collaborators in alert tasks increased (in 1962 the River Nursery Corps was created). However, meteorological and hydrological forecasting systems continued to be too generic and little precise. In the late 1980s, the Automatic Hydrological Information Service (SAIH) was installed and perfected until it became an automated data transmission system for rainfall and river flows in real time. Despite all these advances, short and medium term meteorological and hydrological forecasting remains difficult. In the last catastrophic episode of January 2020, uncertainty of the forecasts prevented the ACA to release more water from the reservoirs before the storm so the rapid accumulation to risky levels forced larger releases of water that caused inundations downstream (La Vanguardia, 24/1/2020).

Finally, at the beginning of the 1980s, the Generalitat of Catalonia and the municipalities promoted the drafting and implementation of emergency plans at regional and local scales. In the Ter basin, most municipalities have flood emergency planning, although with very uneven states of updating and implementation. The storm Gloria highlighted positive aspects of emergency planning such as the work carried out by Civil Defense personnel, firefighters, rural agents, volunteers and the media. Some aspects needing improvement must be mentioned as well. First, the little information available to the mayors of the small towns in the Middle lower and Lower basin about the development of the flood wave. Second, the early lifting of confinement in some towns when the most important flood peak had not yet arrived. And finally, the curiosity inherent in the human condition, turning dangerous events into spectacles, must be mentioned. Many people, unconscious and reckless, accumulated near the river courses, the bridges or under riverside trees at risk of falling due to the storm (Feliu, 2020). 


\section{Discussion and conclusions}

Results of the historical analysis of catastrophic flood episodes in the Ter River basin appear to confirm the decrease in long terms vulnerability to flooding reported for Europe and elsewhere (Neumayer and Barthel, 2011; Jongman, 2015; Prapotny et al., 2018). The breakdown of vulnerability into the three components proposed by the IPCC (exposure, susceptibility and adaptive capacity) has proven a useful framework for explaining this trend. In the Ter River basin exposure to flooding has increased significantly in the last 100 years. While the relationship of this rise with a parallel growth in the frequency and magnitude of floods (possibly linked to climate change) cannot be ruled out, as the Gloria episode of 2020 would suggest, it seems more likely that exposure has increased after the continuous occupation, transformation, and accumulation of material wealth in flood prone land (Barredo, 2009). Hence the steady trend in increasing economic losses characteristic of the Ter basin. Although conclusive evidence cannot be provided due to the paucity of data and lack of specialized economic studies on flood impacts, it is highly likely that losses compared to the evolution of regional GNP (Barredo et al., 2012) would show also a declining trend. The evolution of wealth related indicators such as GDP or Per Capita Family Income in most municipalities included in the flood risk areas of the Middle lower and Lower Ter Basin (ACA, 2019) shows an upward trend, always above average Catalan figures (Ribas and Saurí, 2002; IDESCAT, 2019).

In the study area individual and social susceptibility to flooding appear to have declined mostly through advances in human welfare and better conditions in work, housing and general standards of living than in the past. Regarding social susceptibility, the increase in material wealth and in democratic governance, among other social gains, has also ensured a diminishing susceptibility to flood impacts. In terms of adaptive capacity, the Ter River case exemplifies the progressive construction of a comprehensive flood management approach in which large flood control works (reservoirs, embankments, channelization, etc.) still play a dominant role in protecting people and goods from extreme events. However, progress in flood forecasting and warning together with emergency planning has been also remarkable and helps to explain why events of a large magnitude such as Gloria do not cause human casualties. Post disaster relief measures have also improved especially through the generalization of insurance (Kron, 2015). As a result of this progress, flood management in the Ter River basin is becoming more comprehensive, more diversified and more complex as well.

However, many challenges remain. Perhaps the most important is the role of land use planning in reducing exposure. Partly inspired by the Dutch experience, the flood Directive of 2007 introduced a fundamental change in flood management. Admitting the impossibility of suppressing these phenomena with hydraulic works, the Directive adopted the principle of "living with floods" or the need of rethinking the role of large flood control infrastructures and their economic, social and environmental impacts and put a greater emphasis land use planning in floodplains. The Dutch program of "Room for Rivers" represents an example of removing intensive human occupation of floodplains and returning to the river system spaces that not only help to dissipate flood waves but that harbor significant environmental values and services (Warner et al., 2013; Ollero et al., 2015). Still, floodplains are coveted for development and land use plans restricting exposure are difficult to accept especially at the local level because the benefits of development are perceived to be greater than the risks (Lara et al., 2010). In the Ter River, post recovery action after Gloria has been primarily aimed at reconstructing infrastructure and other assets that permitted the continued occupancy of floodplains in the lower basin missing the opportunity of alternative approaches in flood management, most notably the deintensification of land uses (Rode, 2014).

At any rate, storm Gloria could imply a turning point in flood management because very clearly for the first time the event was associated to climate change. Moreover, the increasing recognition of floodplain ecosystems of spaces of value that need protection from development has also contributed to limit and occasionally revert intensive occupation as the Pletera project in the lower basin demonstrates. If after one hundred years it can be forcefully argued that society in the Ter River basin is becoming less 
vulnerable and more resilient to flooding perhaps it is time to direct the next management efforts to enhance the condition of resources that many times in the past floods have enjoyed and reduce their risk potential. Floodplains may offer multiple environmental and resource services to society if their ecosystems are in good state and able to provide economic value.

However, the line between resources and hazards in water is very thin as could be seen in the difficulties experienced by the Ter reservoirs in routing flows during Gloria. Before the event, water stored in the reservoirs was a resource to be used in hydroelectrical production, irrigation and water supply. The massive arrival of upstream flows from heavy rain meant that for security reasons reservoirs had to release water that caused unintended flooding downstream. If floods will become more likely under climate change, the challenge is not only to learn to live with them but also to appreciate the multiple benefits they may provide if properly managed. In the Ter basin and elsewhere in Catalonia, storm Gloria opened an important debate on this change of perception. However, barely a few weeks after the pandemic and the associated economic and social crisis will surely bring more pressures to continue with the existing state of affairs.

\section{References}

ACA (Agència Catalana de l'Aigua) 2018. Pla de gestió del risc d'inundació del districte de conca fluvial de Catalunya, available at: http://aca.gencat.cat/ca/plans-i-programes/gestio-del-risc-dinundacions/1ercicle-de-la-gestio-dels-risc-dinundacions/. Date of access June 8, 2020.

ACA (Agència Catalana de l'Aigua) 2019. Revisió i actualització de l'avaluació preliminar del risc d'inundació del districte de conca fluvial de Catalunya (2n cicle), available at: http://aca.gencat.cat/ca/plans-iprogrames/gestio-del-risc-dinundacions/2n-cicle-de-la-gestio-del-risc-dinundacions/. Date of access June 8, 2020.

AEMET 2015. Proyecciones climáticas para el siglo XXI en España, available at: http://www.aemet.es/es/serviciosclimaticos/cambio_climat. Date of access June 8, 2020.

Alfieri, L., Burek, P., Feyen, L., Forzieri, G. 2015. Global warming increases the frequency of river floods in Europe. Hydrology and Earth System Sciences 19, 2247-2260. https://doi.org/10.5194/hess-19-22472015.

Angelakis, A.N., Antoniou, G., Voudouris, K., Kazakis, N., Dalezios, N., Dercas, N. 2020. History of floods in Greece causes and measures for protection. Natural Hazards 101, 833-852 (2020). https://doi.org/10.1007/s11069-020-03898-w.

Barbaza, Y. 1988. El paisatge humà de la Costa Brava. Edicions 62, Barcelona.

Barredo, J. I. 2009. Normalised flood losses in Europe: 1970-2006. Natural hazards and earth system sciences 9 , 97-104. https://doi.org/10.5194/nhess-9-97-2009.

Barredo, J. I., Saurí, D., Llasat, M. C. 2012. Assessing trends in insured losses from floods in Spain 1971-2008. Natural hazards and earth system sciences 12, 1723-1729. https://doi.org/10.5194/nhess-12-1723-2012.

Blaikie, P., Cannon, T., Davis, I., Wisner, B. 2005. At Risk: Natural Hazards, People's Vulnerability and Disasters. Routledge, New York.

Burton, I., Kates R.W., White, G.F. 1978. The Environment as Hazard. Oxford University Press, New York.

Codinachs, D. 1994. Geografia històrica de les inundacions en un àrea de muntanya: el cas del Ripollès. Treballs de la Societat Catalana de Geografia 38, 93-102.

Comisaría General de Regiones Inundadas 1942. Memoria de la labor desarrollada por la Comisaría General en reconstrucción de los daños ocasionados por las inundaciones en 1940 (Gerona), 171, Talleres Gráficos Antonio J. Rovira, Barcelona.

Consorci del Ter, Fundació AGBAR 2004. Atles ambiental i patrimonial del riu Ter. Consorci del Ter. Girona.

Díaz, E. 1989. Evolució històrica de la previsió d'avingudes. Dominar l'aigua. Espais, 19, 25-28. 
EEA (European Environment Agency) 2016. Floodplain Management: Reducing Flood Risks and Restoring Healthy Ecosystems, Copenhaguen, EEA, available at: http:/www.eea.europa.eu/downloads/ 3b859c033b6249c79c9a9fab89b96957/1466520374/floodplain-management-reducing-flood-risks.pdf. Date of access June 8, 2020.

Ensor, J.E., Park, S.E., Hoddy, E.T., Ratne, B.D. 2015. A rights-based perspective on adaptive capacity. Global Environmental Change, 31, 38-49. https://doi.org/10.1016/j.gloenvcha.2014.12.005.

Feliu, P. 2020. Glòria al Ter. El Punt Avui, January 28, 2020, available at: https://www.elpuntavui.cat/societat/article/5-societat/1730643-gloria-al-ter.html. Date of access June 8, 2020.

Gobierno Civil de Gerona 1964. Gerona. Inundaciones. Memoria, Gobierno Civil de Gerona. Girona.

Gobierno Civil de Gerona 1970. Informe que se eleva al gobierno al amparo del decreto 2096/69 de 13 de noviembre en relación con las inundaciones registradas los días 11 y 12, Gobierno Civil de Gerona, Girona.

IPCC 2014. Climate change 2014: impacts, adaptation, and vulnerability: Working group II contribution to the fifth assessment report of the intergovernmental panel on climate change, available at: www.ipcc.ch. Date of access June 8, 2020.

Jongman, B., Winsemius, H. C., Aerts, J. C., De Perez, E. C., Van Aalst, M. K., Kron, W., Ward, P. J. 2015. Declining vulnerability to river floods and the global benefits of adaptation. Proceedings of the National Academy of Sciences 112 (18), E2271-E2280. https://doi.org/10.1073/pnas.1414439112.

Kron W. 2015. Flood disasters-a global perspective. Water Policy 17, 6-24. https://doi.org/10.2166/wp.2015.001.

La Vanguardia. 24/1/2020. La ACA alega que no desembalsó antes los pantanos porque las previsiones eran inciertas, available at: https://www.lavanguardia.com/vida/20200124/473097790715/aca-alega-que-nodesembalso-antes-pantanos-porque-previsiones-eran-inciertas.html. Date of access June 8, 2020.

Lara, A., Saurí, D., Ribas, A., Pavón, D. 2010. Social perceptions of floods and flood management in a Mediterranean area (Costa Brava, Spain), Natural Hazards and Earth Systems Sciences 10, 2081-2091. https://doi.org/10.5194/nhess-10-2081-2010.

Llansó de Viñals, J.M. 1971. Estudios y proyectos para preservar de inundaciones la ciudad de Gerona, Cámara Oficial de Comercio e Industria de Gerona, Girona.

Llasat, M. C., Barriendos, M., Barrera, A., Rigo, T. 2005. Floods in Catalonia (NE Spain) since the 14th century. Climatological and meteorological aspects from historical documentary sources and old instrumental records. Journal of Hydrology 313 (1-2), 32-47. https://doi.org/10.1016/j.jhydrol.2005.02.004.

Mudelsee, M., Börngen, M., Tetzlaff, G., Grünewald, U. 2003. No upward trends in the occurrence of extreme floods in central Europe. Nature 425, 166-169. https://doi.org/10.1038/nature01928.

Munich RE 2019. Risks from floods, storm surges and flash floods, available at: https://www.munichre.com/en/risks/natural-disasters-losses-are-trending-upwards/floods-and-flashfloods-underestimated-natural-hazards.html. Date of access June 8, 2020.

Neumayer, E., Barthel, F. 2011. Normalizing economic loss from natural disasters: a global analysis. Global Environmental Change 21, 13-24. https://doi.org/10.1016/j.gloenvcha.2010.10.004.

Olcina, J., Saurí, D., Hernández, M., Ribas, A. 2016. Flood policy in Spain: a review for the period 1983-2013. Disaster Prevention and Management: An International Journal 25/1, 41-58. https://doi.org/10.1108/DPM-05-2015-0108.

Ollero, A., Ibisate, A., Granado, D., Real de Asua, R. 2015. Channel responses to global change and local impacts: perspectives and tools for floodplain management (Ebro River and tributaries, NE Spain. In: P. Hudson, H. Middelkoop, H. (Eds), Geomorphic Approaches to Integrated Floodplain Management of Lowland Fluvial Systems in North America and Europe, Springer, New York, pp. 27-52. https://doi.org/10.1007/978-1-4939-2380-9_3.

Paprotny, P., Sebastian, A., Morales-Nápoles, O., Jonkman, S.N. 2018. Trends in flood losses in Europe over the past 150 years. Nature Communications 9, 1985. https://doi.org/10.1038/s41467-018-04253-1. 
Pascual, J. 2005. Les esllavissades de 1994 a l'Estartit. La Punxa, Col·legi Oficial d'Aparelladors i Arquitectes Tècnics 39, 26-37.

Pueyo-Ros, J., Ribas, A., Fraguell, R.M. 2017. Uses and Preferences of Visitors to Coastal Wetlands in Tourism Destinations (Costa Brava, Spain). Wetlands, 38(6), 1183-1197. https://doi.org/10.1007/s13157-0170954-9.

Pueyo-Ros, J., Garcia, X., Ribas, A. Fraguell, R.M. 2018. Ecological restoration of a coastal wetland at a mass tourism destination. will the recreational value increase or decrease? Ecological Economics 148, 1-14. https://doi.org/10.1016/j.ecolecon.2018.02.002.

Ribas, A. 1994. Natura, societat i calamitat. Una aproximació a les inundacions històriques de la ciutat de Girona. Bellaterra. Universitat Autònoma de Barcelona, available at: https://www.tdx.cat/handle/10803/4985. Date of access June 8, 2020.

Ribas, A. 2007. Les inundacions a Girona. Ajuntament de Girona and Institut d'Estudis Gironins. Girona (col. Patrimoni Cultural, 6).

Ribas, A. 2009. Las inundaciones en la ciudad de Girona: Una perspectiva histórica. In: A. Alberola, J. Olcina, J. (Edrs.), Desastre natural, vida cotidiana y religiosidad popular en la España moderna y contemporánea. Publicaciones de la Universidad de Alicante, Alicante, pp. 287-334.

Ribas, A., Saurí, D. 1993. L'aiguat d'octubre de 1940 a les conques dels rius Ter, Fluvià i Muga. In: J. Bécat, G. Soutadé (Edrs.), L'aiguat del 40. Inundacions catastròfiques i polítiques de prevenció a la Mediterrània nord-occidental. Departament de Política Territorial i Obres Públiques. Generalitat de Catalunya, Barcelona, pp. 147-158.

Ribas, A., Saurí, D. 2002. Els impactes territorials dels transvasaments hídrics: una mirada retrospectiva al transvasament del Ter. In: Els transvasaments en la història de Catalunya. Fundació Pere Garcia Faria, Girona, pp. 121- 130 .

Ribas, A., Serra, D. 2009. Canvi global i riscos naturals. El cas de la Costa Brava. In: C. Barriocanal, D. Varga, J. Vila (Edrs.), Canvi ambiental global. Una perspectiva multiescalar. Documenta Universitaria, Girona, Col. Quaderns de Medi Ambient 1, pp. 135-151.

Ribas, A., Olcina, J., Saurí, D. 2020, More exposed but also more vulnerable? Climate change, high intensity precipitation events and flooding in Mediterranean Spain. Disaster Prevention and Management 29(3), 229-248. https://doi.org/10.1108/DPM-05-2019-0149.

Rode S. 2014. Une Zone d'Aménagement Différé pour rétablir un champ d'expansion des crues. In: Scarwell H.J., Schmitt G., Salvador P.-G. (Edits.), Urbanisme et inondation: outils de réconciliation et de valorization. Presses Universitaires du Septentrion, col. Environnement et Société, pp. 127-148. https://doi.org/10.4000/books.septentrion.17411.

Rosenzweig, B. R., McPhillips, L., Chang, H., Cheng, C., Welty, C., Matsler, M., Iwaniec, D., Davidson, C. I. 2018. Pluvial flood risk and opportunities for resilience. Wiley Interdisciplinary Reviews: Water 5 (6), e1302. http://doi.or/10.1002/wat2.1302.

Roset, D., Saurí, D., Ribas, A. 1999. Las obras hidráulicas en los sistemas fluviales de la Costa Brava: preferencias locales y limitaciones de un modelo convencional de adaptación al riesgo de inundación. Investigaciones Geográficas, 22, 79-93. https://doi.org/10.14198/INGEO1999.22.07.

Saurí, D., Ribas, A., Sorribas, E., Roset, D. 1993. Inundacions i societat al Baix Ter, Dalmau Carles Pla, Girona.

Saurí, D. 2011. Crisi econòmica I riscos naturals. Revista Catalana de Seguretat Pública 24, 27-44.

Schmidt-Thomé, P., Grieving, S. (Eds.) 2013. European Climate Vulnerabilities and Adaptation. Chichester, UK, Wiley.

Schumacher, I., Strobi, E. 2011. Economic development and losses due to natural disasters: The role of hazard exposure. Ecological Economics 72, 97-105. https://doi.org/10.1016/j.ecolecon.2011.09.002.

Tanoue, M., Hirabayashi, Y., Ikeuchi, H. 2016. Global-scale river flood vulnerability in the last 50 years. Nature Scientific Reports 6, Nature Publishing Group, Berlin, p. 36021. https://doi.org/10.1038/srep3602. 
UNISDR (United Nations International Strategy for Disaster Reduction) and CRED (Centre de Recherche d'Épidémologie des Desastres) 2019. The human cost of weather related disasters, available at: www.unisdr.org/files/46796_cop21weatherdisastersreport2015.pdf. Date of access June 8, 2020.

Vilaplana, J.M. 2008. RISKAT. Els riscos naturals a Catalunya, Informes del CADS 6. Generalitat de Catalunya, Barcelona.

Warner, J.F., Van Buuren, A., Edelenbos, J. (Eds.) 2013. Making Space for the River: Governance Experiences with Multifunctional River Flood Management in the US and in Europe, IWA Publishing, Chicago, IL.

Winsemius, H. C., Aerts, J. C., Van Beek, L. P., Bierkens, M. F., Bouwman, A., Jongman, B., Kwadijk, J.C., Ligtvoet, W., Lucas, P.L., van Vuuren, D.P., Ward, P. J. 2016. Global drivers of future river flood risk. Nature Climate Change 6(4), 381-385. https://doi.org/10.1038/nclimate2893. 